\title{
Quality Control and Management in Data Production Process of High-speed Railway Settlement Observation
}

\author{
Chao Chen (Corresponding author) \\ Faculty of Geosciences and Environmental Engineering, Southwest Jiaotong University \\ Northbound 111 of Second Ring road, Chengdu 610031, Sichuan, China \\ Tel: +86-136-080-79737Ｅ-mail: djycc136@163.com \\ Xianzhou Zhang \\ Faculty of Geosciences and Environmental Engineering, Southwest Jiaotong University \\ Northbound 111 of Second Ring road, Chengdu 610031, Sichuan, China \\ Tel: +86-186-281-72853Ｅ-mail: xzzhangswjtu@163.com \\ Ke Chen \\ Faculty of Geosciences and Environmental Engineering, Southwest Jiaotong University \\ Northbound 111 of Second Ring road, Chengdu 610031, Sichuan, China \\ Tel: +86-151-981-15313Ｅ-mail: djycc136@yahoo.com.cn \\ Jinguang Shang \\ Faculty of Geosciences and Environmental Engineering, Southwest Jiaotong University \\ Northbound 111 of Second Ring road, Chengdu 610031, Sichuan, China \\ Tel: +86-134-084-98636Ｅ-mail: 370833166@qq.com
}

Received: October 7, 2011

Accepted: October 26, 2011 Published: Decemebr 15, 2011

doi:10.5430/jms.v2n4p26

URL: http://dx.doi.org/10.5430/jms.v2n4p26

\begin{abstract}
High smoothness and high stability are two most important characteristics in High-speed railway, which determine the significance and importance of settlement and deformation monitoring of underline engineering. The settlement observational data is complex and massive, only by reasonable and effective quality control and management, can we ensure high-speed railway's be successfully constructed. This article sets up a strict quality control and management measures through disassembleing the procedure of settlement observational data production, to make the procedure standardized and institutionalized, and ensure the settlement observation successful implementation. Meanwhile, establish a timely quality information feedback mechanism of settlement observational data, achieve reliable and controllable settlement observation, and improve the production quality of settlement observational data to ensure high-speed railway's construction.
\end{abstract}

Keywords: High-Speed Railway, Settlement Observation, Data Management, Quality Control, Process Control

In recent years, with the rapid development of economic construction in China, high-speed railway construction is much more developed. High smoothness and high stability are two most important characteristics in high-speed railway, which determine the significance of Settlement and deformation monitoring. The ballastless track of high-speed railway is strict with post-construction settlement of underline engineering. However, the influence factors of settlement are much more. Therefore, it must monitor settlement of underline engineering.

Actually, high-speed railway settlement observation is a data production process with strict operation. Also, the products of settlement data are great massive and complicated, so the quality control is a even more complex systematic 
engineering. It involves many theory and technology, such as management theory, control theory, production technology, computer technology and knowledge of instrument, and has many characteristics be strong theoretical, comprehensive, practical and procedural. Through strictly control and manage data production process of settlement observational data, this article wants to establish a timely quality information feedback mechanism of settlement observational data. Only in this way, can it reduce energy consumption of producing; improve quality of settlement data and the efficiency of producing and lay the foundation for settlement evaluation of underline engineering for later.

\section{Introduce Settlement Observation of High-Speed Railway}

Settlement observation and evaluation for underline engineering of high-speed railway are key link before paving ballastless track. Doing a good job of settlement observation and evaluation is great important for constructing, operating and maintaining high-speed railway. Paving ballastless track is very strict with settlement of underline engineering, which must ensure post-construction settlement is no more than $15 \mathrm{~mm}$, the difference of transition section's uneven settlement (transition of bridge-road and road-tunnel structures) must be no more than 5mm and the longitudinal deformation bevel not beyond 1/1000. During the construction, settlement observation must be conducted systematically based on the requirement of design. Through synthetic analyses and estimation of settlement observational data, we can check or adjust the design, and make the deformation of roadbed, bridge and tunnel to meet the controlling requirement. Lastly, it will be helpful for us to analyze and calculate the final settlement and post-construction settlement, to determine the starting time of paving ballastless track and ensure the paving quality.

\subsection{The Technical Requirements of Settlement Observation}

The deformation of underline engineering is an important parameter of ballastless track railway, which always runs through every stage of design, construction, operation and maintenance in high-speed railway. In order to make this important parameter obtained scientifically, reliably and continuously, the settlement-measuring method should be programmed and designed during the stage of engineering design, and the settlement-monitoring network of underline structure should be established to observe settlement observation during constructing stage. According to High-speed railway engineering surveying rules(TB10601-2009), engineering control network of high-speed railway uses 1985 national height system, and vertical displacement monitoring of underline engineering is on the basis of the third class of building deformation measurement (second class national leveling) to implement.

$<$ Table 1 about here $>$

According to the characteristics of high precision for settlement deformation, monitoring network should set up by classification and control step by-step. Constitute closed leveling circuit or annexed leveling line.

$<$ Table 2 about here>

\subsection{The Measuring Point Layout Requirements of Settlement Deformation Observation}

Measuring point of settlement deformation can be divided into datum mark, working point and deformation monitoring point. In order to preserve for a long time, datum mark should be embedded in a stable position, Which is outside the affection region of deformation. Each independent monitoring network should contain no fewer than three solid and reliable datum marks, and the distance between datum marks should be no more than $1 \mathrm{~km}$. The position of working point should be a stable place and the distance between working points is common $200 \mathrm{~m}$. Deformation monitoring point should be embedded in the position which is the deformation characteristic of transformational structure. Deformation monitoring point not only requires setting firmly, observing easily, but also requires the form is beautiful, the structure is reasonable, and cannot destroy the appearance and using of transformational structure. Deformation observation point is mainly settlement plate, observing point and profile pipe of roadbed section, monitoring point of cushion cap, pier column and other underline structures.

\subsection{The Requirement for Instrument and Monitoring Method of Settlement Observation}

By the requirements of high stability and smoothness, high-speed railway changes the traditional monitoring instrument of precision optical level into precision electronic level. It has greatly reduced the man-made errors, improved the accuracy and reliability of the settlement data and attended to high precision, which was vulnerably influenced by varieties of external factors. In order to ensure data quality reliability, settlement observation should abide by the principle of "five fixed", which are fixing observation route, observation method, observation person, fixing measuring instrument and equipment, and be in the same environment or condition.

\subsection{The Requirement for Time and Frequency of Settlement Observation}

Settlement observation of underline structure is strict with observing time in high-speed railway. It should accord the scheme of surveying plan to observe, especially the first period observation must implement on time. Only in this way 
can we get systematic, accurate settlement law. Normally, the time of settlement observation should strictly accord the request of The technical guidelines for paving ballastless track condition assessment of passenger dedicated railway. The specific requirement shows in table 3.

$<$ Table 3 about here>

\section{The Process Management and Control of Producing Settlement Observational Data}

\subsection{The Management for Preliminary Work of Settlement Observation}

Before starting settlement observation, the unit of capital construction, design, evaluation, and supervision should organize conferences. Each unit should turn over technical clarification to make clear requirement, and form the work plan or report finally. The specific content shows in table 4.

$<$ Table 4 about here>

\subsection{The Management for Project Property Information of Settlement Observation}

In order to implement programmed management of settlement observation, evaluation unit should require construction unit to submit project property information of settlement observation timely, which mainly involves general situation of the construction and the detailed information of settlement observation control network and observation point. The main contents are:

1.The attribute information files of settlement observation point;

2.The position maps of laying settlement observation point;

3.The achievement elevation of settlement observation working point;

4.The format for data folder of settlement observation;

5.The pictures and the descriptions of datum mark, working point and monitoring point.

Based on the position of observation cross-section, design unit should fill design settlement value in a table, and submit it to capital construction unit, construction unit and evaluation unit. Simultaneously, design unit should provide the relevant engineering design documents for capital construction unit and evaluation unit, which are including the type of underline structure, complete geological data and corresponding engineering measures.

\subsection{The Management for Field Supervision of Settlement Observation}

Before carrying out settlement observation, supervision unit should check up the situation of laying observational network and observation point, the buying situation of equipment by construction unit, audit the qualification of observation person and instrument certificate, and write the review report. Next, supervision unit should organize professional persons to visual inspection, establish work attendance checking system for checking field observation person of construction unit to ensure observation is strictly implemented in accordance with "Prepare work of Settlement and deformation observation”. Meanwhile, supervision unit should regularly organize professional observation person to carry out parallel observation by using the same observation manner of construction unit, and write monthly parallel observation report.

\subsection{The Quality Assessment of Settlement Observational Data}

\subsubsection{Encoding Rules of Observation Point}

In order to effectively and systematically manage and analyze, mass settlement observational data must combine the technological requirement of high-speed railway with the data format the database software to adopt uniform standard and format for complete railway line. The named format of observation point should concisely reflect mileage, type and position of point. Concrete encoding can adopt the following way:

Mileage Type Position

Mileage can adopt seven Arabic numerals, the first 4 for kilometer stake, and the back 3 for hectometer stake (integer); The point type encoding use one English letter; The point position encoding use one Arabic numeral. Observation point adopts nine numerals to code. Detailed encoding method is show in Table5.

\section{$<$ Table 5 about here $>$}

\subsubsection{Examining In-Stockroom Operation of Settlement Observational Data}

The primary purpose of settlement observation is getting through settlement observational data to reflect the settlement of underline engineering, therefore the quality of settlement observational data is very important to control underline 
engineering settlement. Before the settlement evaluation, construction unit should make full use of the management software of settlement observational data to examine the data quality. In order to avoid entering error messages into database maximally, the quality of whole settlement observational data must conduct strict control. The specific content of the inspection is as follows:

1. The quality control of settlement value: The quality control would start mainly from the following aspects: single settlement value, accumulative settlement value, the difference settlement value between different observation marks of same section and the difference settlement value between adjacent sections. According to the decision criteria of The technical guidelines for ballastless track laid condition assessment of passenger dedicated railway and the experience which is gained from the settlement evaluation work of several high-speed railways in china, this article proposes the quality control should adopt the following way: Single settlement value is less than -2mm or greater than $4 \mathrm{~mm}$. Accumulative settlement value is greater than $15 \mathrm{~mm}$. Observation point is rising and the value is more than $2 \mathrm{~mm}$. The difference of accumulative settlement value between different points in the same section is greater than $3 \mathrm{~mm}$. The difference of accumulative settlement value on adjacent sections is greater than $5 \mathrm{~mm}$. When the settlement data shows afore-mentioned situations, data manager should calculate and analyze these suspected abnormal situations, and carry out dynamic monitoring by a informational way to monitor the change and development of these suspected abnormal situations.

2. The quality control of point attribute: The actual encoding of measuring point is or is not correspond to the encoding of attribute table. The information of project property does or does not input. The information of broken height does or does not correctly input. Whether there is or not any problem of missing issue of measuring.

3. The quality control of settlement observational data file: The naming of settlement observational data file is or is not correct. The format of settlement observational data file is or is not correct. The settlement observational data file is or is not missing. The closing error and mean square error of settlement observation route are or are not transfinite.

Generally, the operation of in-stockroom for settlement observational data is performed once a month (if there has large amount of data and the frequency can be reduced to half a month). Before the in-stockroom operation, the above content must be examined thoroughly. If afore-mentioned circumstances appear, data manager should promptly contact with construction unit, and provide detailed investigate report. Construction unit should be according to the content of the report to investigate the course of settlement observation and data processing, and timely write a report of rectification measures. If there is no abnormalities, construction unit can write a simple report to explain, but must enhance the later settlement observation to validate the measuring data.

\subsection{The Control for Sampling Settlement Observation}

\subsubsection{The Control for Parallel Observation of Supervision Unit}

For checking observation result of construction unit, supervision unit must conduct parallel observation. Supervision unit should organize professional person, use the same level route of construction unit to observe. According to the guidance of Prepare work of parallel observation, parallel observation must carry out strictly and independently, and forbid directly using the focusing mirror to read data by construction unit observer.

Generally, the ratio of parallel observation points should be not less than $10 \%$ of construction unit and for the section of complex geologic, biggish settlement changing and the transiting section should be not less than 20\%. Parallel observation section should evenly cover the whole observation section; furthermore, parallel observation should choose a key section to monitor intensively, and get the full settlement observational data to compare with construction unit. If there appears a big difference, Supervision unit should inspect themselves at once, then request construction unit to examine their own settlement observational data, at the same time Supervision unit should inform Capital construction unit and design unit to audit. Supervision unit should provide load - time - settlement developing process line (P - T - the S curve) to evaluation unit, which is on the base of parallel observation.

\subsubsection{The Control for Sampling Observation of Evaluation Unit}

Underline engineering settlement observational data is particularly important for predicting post-construction settlement in high-speed railway. In order to ensure settlement observational data of construction unit is reliable, evaluation unit should be according to the Spot checking work to examine the settlement observation of construction unit.

Field sampling must cooperate with construction unit, and accord the settlement observation schedule to observe. Sampling date should be close to the time of construction unit as far as possible. The first period sampling must cover the whole settlement observation section, which means the whole working points and deformation monitoring points. The later period sampling can be according to the specific circumstances to implement, but before assessment, 
evaluation unit must sample the whole settlement observation section again.

First-term sampling data should timely compare with the first-term data of construction unit. Evaluation unit should seriously check the difference, systematically analyze the abnormalities between evaluation unit and construction unit, and form a detailed description report about the result of comparing data. Evaluation unit should compile field sampling work report monthly. In the report, sampling observers should elaborate the detail about field sampling, including the condition and environment of settlement observation, the protecting status of working point and measuring point, the progress of the project phase, the situation of data comparison, especially the analysis of abnormal situation.

\section{The Methods of Data Quality Control and Management}

\subsection{Perambulation and Inspection}

In the process of producing settlement observational data and in-stockroom operation, perambulation and inspection is premise of data quality control. Before starting settlement observation, inspector should inspect the on-the-spot condition to ensure the stability of settlement observation point meets the requirement. When observing, inspector must implement visual supervise to ensure that observer is in accordance with the requirement to observe, and make guidance for settlement observation problems at any time. In the process of data processing and in-stockroom, inspector should supervise the operations, make sure the data is objective which is without man-made factors and the whole operations can meet the requirements of relevant standards.

\subsection{Set Testing Section of Settlement Observation}

High-speed railway is a very complicated systematic project, which involves many key technologies of many areas. Construction unit must advanced research those key technologies for high-speed railway construction ${ }^{[8]}$. Settlement observation is also like this, construction unit should strictly accord Prepare work of Settlement and deformation observation to set the testing section, and explore the method of purifying and decomposing measuring process. In this way, construction unit can summarize the experience and key technique of settlement observation to study how to improve their efficiency, and provide technical guidance and referential experience for all line settlement observation in the later stage.

\subsection{Set Key Quality Control Points}

In the process of producing settlement observational data and in-stockroom operation, controlling key quality points is kernel of quality control. In this paper, the key quality control points are setting as follows:

1. Personnel quality and instrument accuracy. Settlement observation is very important to safeguard the high-speed railway construction. Subjectively, settlement observers should love surveying and have strong responsibility for railway enterprise. Objectively, observers is the main body to acquire the settlement observational data, who must be proficient in settlement observation method and have the corresponding qualifications. Settlement observation instrument is a specific tool of data acquisition; its precision must meet relevant regulations.

2. The embedment and protection of datum mark, working point and deformation monitoring point must be reasonable and strict, and should comprehensively consider the influence of the whole construction stage. In this way, those equipments of points can be coordinated with construction and not interfered with each other. Settlement observation should directly act on the monitoring point. If the monitoring point changes or breaks, it must affect the data quality of settlement observation and even makes later observation not continue. Therefore, it is important to ensure the monitoring point is stable and safe.

3. The time and frequency of settlement observation. Enough settlement observation time is necessary condition to develop settlement of engineering structure and obtain sufficient observed data, and it is the assurance of predicting post-construction settlement and the basis of accurate judging stability. Settlement observation time must meet the minimum requirement of evaluation. The specific requirements can see table 3 . Observation frequency must be able to systematically record the settlement changing process of observed object, which can fully and accurately reflect the characteristics and time relationship of settlement. Theoretically, more times and much higher frequency can record more information of settlement, and be better for forecasting analysis of settlement evaluation. However, due to the restriction of observation accuracy, higher frequency cannot be effectively reflect information of settlement changing, instead, it will cause the information of settlement get covered up, because observation data is mixed a lot of error. Therefore, a reasonable observation frequency can not only record settlement feature truly, but also reduce the settlement observation workload.

4. Quality auditing of in-stockroom data. The direct aim of settlement observation is to acquire settlement data, the fundamental purpose is to evaluate the stability of underline engineering, and the ultimate goal is to ensure construction 
of high-speed railway. This suggests that settlement data is the most important factor of settlement observation and evaluation. All the work should be carried out on the based of settlement data. Therefore, the meaning of controlling the quality of in-stockroom data may be different from common. The specific operation can be according to the requirements of this paper 3.4 .

5. Draw the load - time - settlement curve of observation point. According to the settlement observational data, construction unit and supervision unit should draw the load - time - settlement curve to timely know the settlement development trend. The quick developing section and abnormal settlement points should be monitored at any time with the help of information technology, analyze the reason of the above abnormal condition, and take effective measures to guide the construction.

\subsection{Establish Knowledge Base of Quality Control}

In the process of obtaining and storing settlement observational data, establishing knowledge base of quality control is the foundation of quality management.

High-speed railway is a very complicated systematic project, which involves many key technologies of many areas, such as various national regulations, industry standards and many other technical standards. Settlement observation also involves various knowledge and experience, which can be not fully mastered by an independent person. Therefore, summarize these complicated technical specifications, industry standards and expert experience together and establish knowledge base of quality control to manage settlement observation, so that we can find out the way to ensure the high quality of settlement observational data. The settlement observational data is also complex and huge. For example, a hundred kilometers railway is likely to have hundreds of thousands of settlement observational data. If we simply depend on person to manage and check the data, the work can be impossible to accomplish. Therefore, the work must be carried out by computer system to greatly help staff manage and review data, so it is important to make the experience of data anomalies into the knowledge, which can be recognized with the help of computer system. Based on the programmed management of settlement observation and data entry, it can build a knowledgebase platform to design and manage quality control points. In this way, it will greatly exert the collective wisdom, effectively achieve the aim of controlling quality key points, ensure settlement observational data is in high quality and high reliability and form a dynamic monitoring system for the whole settlement process, so as to realize the goals of quality control.

$<$ Figure 1 about here $>$

\section{Peroration}

High-speed railway is a very complicated systematic project. Settlement observation has important meaning to ensure the construction of high-speed railway. This paper is through programmed management and reified examining of data entering to set up a strict quality management and control measures to realize the process control and high efficiency managing of settlement observation. In order to be better servicing for construction of high-speed railway, this article is based on the data management practice of high-speed railway to propose some superficial views, and hope it can provide some references to a person of the same trade or occupation.

\section{Reference}

Huang, J. (2005). Design Provisions for Dedicated Passenger Railway Line Overview. Railway Science Academy.

Wu, D. etc, (2010). Analysis of high-speed railway settlement observation data processing. Journal of Railway Science and Engineering. 7(2), pp.89-92.

Chen, S. etc, (2010). Evaluation of high-speed railway settlement theory and practice of observation. China Railway Publishing House.3.

Li, M. (2009). The settlement observation and evaluation techniques for passenger railway line ballastless track.. China Engineering Science. 48(1), pp.21-28.

Republic of China Ministry of Railways, (2009). High-speed railway engineering survey Specifications (TB10601-2009). China Railway Publishing House.

Liu, H. (2010). The application of robust kalman filtering in the high-speed railway deformation monitoring. Southwest Jiaotong University. pp.14-15.

Republic of China Ministry of Railways, (2006). Ballastless track condition evaluation guidelines. China Railway Publishing House.

$\mathrm{Xu}, \mathrm{W}$. (1999). Some proposals on construction survey of high-speed railway. Journal of Railway Engineering Society. 4, pp.29-32. 
Table1. The requirement of class and accuracy in settlement observation

\begin{tabular}{|c|c|c|}
\hline Class & $\begin{array}{c}\text { Mean square error of height in settlement } \\
\text { deformation point }(\mathrm{mm})\end{array}$ & $\begin{array}{c}\text { Mean square error of elevation difference in adjacent } \\
\text { settlement deformation point (mm) }\end{array}$ \\
\hline Third & \pm 1.0 & \pm 0.5 \\
\hline
\end{tabular}

Tab 2 The technical requirement of settlement observation network

\begin{tabular}{|c|c|c|c|c|c|}
\hline Class & $\begin{array}{l}\text { Mean square } \\
\text { error of height in } \\
\text { adjacent datum } \\
\text { mark (mm) }\end{array}$ & $\begin{array}{l}\text { Mean square } \\
\text { error of height } \\
\text { in survey } \\
\text { station (mm) }\end{array}$ & $\begin{array}{l}\text { To-and-fro difference, } \\
\text { misclosure of connecting } \\
\text { traverse or closed } \\
\text { traverse(mm) }\end{array}$ & $\begin{array}{c}\text { Difference of } \\
\text { height for } \\
\text { detecting } \\
\text { discrepancy (mm) }\end{array}$ & $\begin{array}{l}\text { Instrument, measuring } \\
\text { method and requirement }\end{array}$ \\
\hline Third & \pm 1.0 & \pm 0.3 & $\begin{array}{l} \pm 0.6 \sqrt{n} \\
\pm 4 \sqrt{F}\end{array}$ & $\begin{array}{l} \pm 0.8 \sqrt{n} \\
\pm 6 \sqrt{R}\end{array}$ & $\begin{array}{l}\text { DS05 or DS1 surveying } \\
\text { instrument, accord to } \\
\text { High-speed } \\
\text { engineering railway } \\
\text { rules. }\end{array}$ \\
\hline
\end{tabular}

n-Measuring sections of stations count, R-Length of the following-line or closed-line, F-Length of detecting measuring section.

Tab 3 The general provisions for time and frequency of settlement observation

\begin{tabular}{|c|c|c|c|}
\hline stages & time & \multicolumn{2}{|c|}{ frequency } \\
\hline \multirow{2}{*}{ Roadbed } & \multirow{2}{*}{$\begin{array}{l}\text { No less than six } \\
\text { months after } \\
\text { main project } \\
\text { completed }\end{array}$} & Filling or preloading & Once a day \\
\hline & & $\begin{array}{l}\text { Preloading or roadbed } \\
\text { construction completed }\end{array}$ & Once a week \\
\hline \multirow[b]{2}{*}{$\begin{array}{l}\text { Bridge and } \\
\text { culvert }\end{array}$} & \multirow{2}{*}{$\begin{array}{l}\text { No less than six } \\
\text { months after } \\
\text { main project } \\
\text { completed }\end{array}$} & Whole course & Once a week \\
\hline & & $\begin{array}{lr}\text { Pier and } & \text { abutment } \\
\text { construction, } & \text { girder } \\
\text { erection, girder } & \text { erection } \\
\text { machine transit } & \end{array}$ & $\begin{array}{l}\text { Each one time for } \\
\text { observing before and } \\
\text { after load changed }\end{array}$ \\
\hline \multirow{3}{*}{ Girder } & \multirow{3}{*}{$\begin{array}{l}\text { No less than six } \\
\text { months after } \\
\text { main project } \\
\text { completed }\end{array}$} & $\begin{array}{l}\text { Tensioning } \quad \text { Prestressed } \\
\text { girder }\end{array}$ & 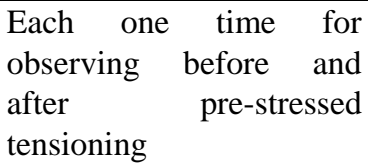 \\
\hline & & $\begin{array}{l}\text { Installing ancillary facilities } \\
\text { of girder }\end{array}$ & $\begin{array}{l}\text { Each one time for } \\
\text { observing before and } \\
\text { after install }\end{array}$ \\
\hline & & $\begin{array}{l}\text { After tensioning prestressed } \\
\text { girder, before laying } \\
\text { ballastless track }\end{array}$ & $\begin{array}{l}\text { One time per one day, } \\
\text { three days, five days, later } \\
\text { stage once a week }\end{array}$ \\
\hline Tunnel & $\begin{array}{l}\text { No less than } \\
\text { three months } \\
\text { after } \\
\text { project } \\
\text { completed }\end{array}$ & \multicolumn{2}{|c|}{ Once a week } \\
\hline
\end{tabular}

The observation time and frequency do not consider with the time after laying ballastless track. 
Tab 4. The work requirement of each unit in settlement observation

\begin{tabular}{|c|c|c|c|}
\hline Unit & $\begin{array}{l}\text { Combined } \\
\text { unit }\end{array}$ & Preparing file or report & Main contents \\
\hline $\begin{array}{c}\text { Capital } \\
\text { construction } \\
\text { unit }\end{array}$ & $\begin{array}{l}\text { Design Unit } \\
\text { Evaluation } \\
\text { Unit }\end{array}$ & $\begin{array}{l}\text { Rules for implementation of } \\
\text { underline engineering } \\
\text { settlement observation and } \\
\text { evaluation (hereinafter } \\
\text { referred to as the “detailed } \\
\text { rules”) }\end{array}$ & $\begin{array}{l}\text { 1. The requirements for each unit of } \\
\text { settlement observation; } \\
\text { 2. The requirements of sitting up } \\
\text { observation sections, laying and protecting } \\
\text { observation marks; } \\
\text { 3. The requirements for precision and } \\
\text { frequency of settlement deformation } \\
\text { observation; } \\
\text { 4. The requirement for management of } \\
\text { settlement observational data and } \\
\text { information. }\end{array}$ \\
\hline Design Unit & $\begin{array}{l}\text { Capital } \\
\text { construction } \\
\text { unit } \\
\text { Evaluation } \\
\text { Unit }\end{array}$ & $\begin{array}{l}\text { Underline engineering } \\
\text { Settlement and deformation } \\
\text { observation program }\end{array}$ & $\begin{array}{l}\text { 1. Set up observation sections; } \\
\text { 2. The requirements for precision and } \\
\text { method of settlement observation; } \\
\text { 3. The requirements for time and frequency } \\
\text { of settlement observation. }\end{array}$ \\
\hline Evaluation Unit & $\begin{array}{c}\text { Capital } \\
\text { construction } \\
\text { unit }\end{array}$ & $\begin{array}{l}\text { Prepare work of spot } \\
\text { checking for Underline } \\
\text { engineering Settlement and } \\
\text { deformation observation } \\
\text { (hereinafter referred to as } \\
\text { the "spot checking work") }\end{array}$ & $\begin{array}{l}\text { 1. The requirements for precision and } \\
\text { frequency of settlement deformation } \\
\text { observation; } \\
\text { 2. Observation organization and personnel } \\
\text { composition of settlement observation. }\end{array}$ \\
\hline $\begin{array}{c}\text { Supervision } \\
\text { unit }\end{array}$ & $\begin{array}{l}\text { Capital } \\
\text { construction } \\
\quad \text { unit } \\
\text { Design Unit } \\
\text { Evaluation } \\
\quad \text { Unit }\end{array}$ & $\begin{array}{l}\text { Prepare work of parallel } \\
\text { observation for Underline } \\
\text { engineering Settlement and } \\
\text { deformation observation } \\
\text { (hereinafter referred to as } \\
\text { the "Prepare work of } \\
\text { parallel observation") }\end{array}$ & $\begin{array}{l}\text { 1. The requirements for precision and } \\
\text { frequency of settlement observation; } \\
\text { 2. Observation organization and personnel } \\
\text { composition of settlement observation; } \\
\text { 3. Abnormal data analysis and measures. }\end{array}$ \\
\hline $\begin{array}{l}\text { Construction } \\
\text { unit }\end{array}$ & $\begin{array}{l}\text { Design Unit } \\
\text { Evaluation } \\
\text { Unit }\end{array}$ & $\begin{array}{l}\text { Prepare work of Underline } \\
\text { engineering Settlement and } \\
\text { deformation observation } \\
\text { (hereinafter referred to as } \\
\text { the "Prepare work of } \\
\text { Settlement and deformation } \\
\text { observation") }\end{array}$ & $\begin{array}{l}\text { 1. Observation sections embedment } \\
\text { program; } \\
\text { 2. The requirements for precision and } \\
\text { frequency of settlement deformation } \\
\text { observation; } \\
\text { 3. Observation agency, personnel and } \\
\text { equipment; } \\
\text { 4. The Special processing mode of special } \\
\text { construction sites. }\end{array}$ \\
\hline
\end{tabular}


Tab 5 Encoding method of point type

\begin{tabular}{|c|c|c|}
\hline Point type & Point type encoding & The position of observation point encoding \\
\hline $\begin{array}{c}\text { Settlement plate } \\
\text { of roadbed }\end{array}$ & L & Substrate (1), surface formation \\
\hline $\begin{array}{c}\text { Observation mark } \\
\text { of roadbed }\end{array}$ & G & Left (1), middle (2), right (3). \\
\hline $\begin{array}{c}\text { Observation mark } \\
\text { of bearing } \\
\text { platform }\end{array}$ & C & Left (1), right (2). \\
\hline $\begin{array}{c}\text { Observation mark } \\
\text { of bridgepier }\end{array}$ & D & Left (1), right (2). \\
\hline $\begin{array}{c}\text { Observation mark } \\
\text { of tunnel }\end{array}$ & S & Left (1), right (2). \\
\hline
\end{tabular}

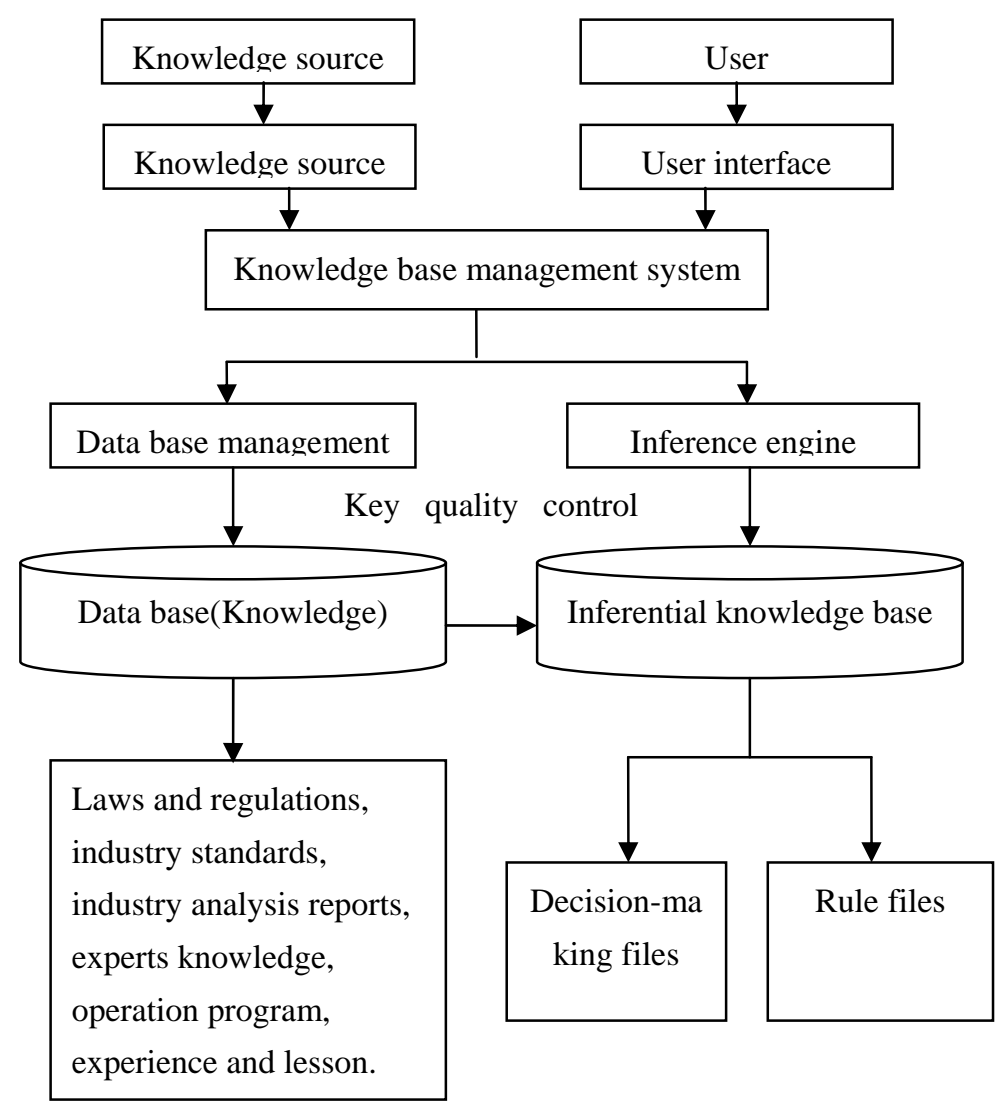

Figure 1. The overall structure of quality control knowledge base system for process control 